primary "group" that organized religion in Africa Proconsularis was the new elite. $^{63}$

Very often, new elite individuals in pursuit of prestige would dedicate a temple or a shrine on behalf of the city, the imperial officials and/or the emperor himself. ${ }^{64}$ Thereby, the new elites established themselves in the eyes of the person (or persons) honored as loyal, devoted and capable, while simultaneously portraying themselves before all those who witnessed the dedication as a person of status, power and prestige. The emperor and imperial officials accepted such dedications, often resulting in the bestowal of citizenship or rank in return; the local people, likely, interpreted them as signs that the dedicator had ties with the emperor and the imperial powers. By carefully, and perhaps naturally, "translating" local gods into Roman deities in these dedications, the new elites mediated between the Roman colonizers and the indigenous Africans, redefining their identity in the eyes of both parties simultaneously.

\title{
6.3 Ancient African Christians and Religious Identity
}

With the introduction of the Christian faith, an untranslatable religion in Roman terms, the complexity increases regarding religious conflict and the formation of a new religious identity. Throughout the empire, Christians received the malignity of non-Christians; however, persecution and the role of martyrdom played a vital role in North African history in the formation of Christians' self-understanding. In order to address this phenomenon the causes of Christian persecutions throughout the empire need delineating.

Scholars have offered a variety of theories to explain the persecution of Christians by Roman authorities. Many suggest some legal basis for the persecution, and, although none still upholds the former view that Nero enacted specific legislation against the Christians, scholars do surmise that Christians could be convicted on the basis of laws pertaining to collegia or superstitio. ${ }^{65}$

63 The following paragraph relies on Rives, Religion. For a similar survey that compares the role of the new elites of North Africa to those of other provinces, see C.R. Whittaker, "Imperialism and Culture: the Roman Initiative," in Dialogues, ed. Mattingly, 143-164.

64 cf. Rives, "Religion," 268. On provincial resistance to the imperial cult, see Beard, North and Price, Religions of Rome, 258. Similarly, see Frankfurter, Religion in Roman Egypt. For a list of extant inscriptions of flamen/sacerdos prouinciae Africae, see Fishwick, The Imperial Cult, 187-204; for Apuleius, Fishwick (195-7), relies on Augustine, Epistula 138.4.19, who says Apuleius was "the priest of a province" [sacerdos prouinciae]. Also, Apuleius, Flor. 16.38, states that "[Someone] even showed, on the evidence of the priesthood I have taken up, that the highest honour in Carthage was mine" [Immo etiam docuit argumento suscepti sacerdotii, summum mihi honorem Carthaginis adesse]. Rives, "The Priesthood of Apuleius," AJP 115 (1994): 273-90, questions this understanding, offering the alternative that he was a priest of Aesculapius.

65 On institutum Neronianum, see discussions in Musurillo, The Acts, lix; and Barnes, "Pagan Perceptions," 233. cf. Tert., Ad nat. 1.7.9; Tacitus, Annals 15.44; and Suetonius, Vita Neronis, 
The majority of scholars, however, remain dissatisfied with legal explanations, because of the inconsistency of persecutions. ${ }^{66}$ Many, moreover, see in the Pliny/Trajan discourse a reflection on Nero's actions, and as a result the procedure of Pliny forms precedence for other provincial officers. ${ }^{67}$ G.E.M. de Ste Croix argues that Pliny's actions did not establish precedence "absolutely," but instead provided the provincial governors with the model by which to work, a model applied with great variance. ${ }^{68}$

While disputes continue over the legal basis of Romans' actions toward Christians, most scholars recognize one factor that contributes to the inconsistent application of persecution: the demands of the local elites. ${ }^{69}$ Commenting on the Pliny/Trajan correspondence, Wilken observes,

Shortly after Pliny's arrival in the city, a group of local citizens approached him to complain about Christians living in the vicinity. What precisely the complaint was we do not know, but from several hints in the letter it is possible to infer that the charge was brought by local merchants, perhaps butchers and others engaged in the slaughter and sale of sacrificial meat. Business was poor because people were not making sacrifices. Towards the end of the letter, written after Pliny had dealt with the problem, he observed that the "flesh of sacrificial victims is on sale everywhere, though up till recently scarcely anyone could be found to buy it."

16.2. For collegia, Wilken, The Christians, 34-5; ref. Tert., Apol. 39. For superstitio, L.F. Janssen, "'Superstitio' and Persecution," in Church and State in the Early Church, in the series Studies in Early Christianity Series, ed. Everett Ferguson, (New York: Garland Publishing, Inc., 1993), 79-107, originally as "'Superstitio' and the Persecution of the Christians," VC 33 (1979): 131-59; and in North Africa, Andrzej Wypustek, "Magic, Montanism, Perpetua, and the Severan Persecution," VC 51 (3 1997): 276-97; Wypustek's arguments assume the PSPF to be Montanist; for a denial of Montanism in the PSPF, see William C. Weinrich, Spirit and Martyrdom: A Study of the Work of the Holy Spirit in Contexts of Persecution and Martyrdom in the New Testament and Early Christian Literature, (Washington, D.C.: University Press of America, 1981), 227-36; Robeck, Prophecy, 13-6; Tilley, "The Passion ," 835; and Rankin, Tertullian, 11, and esp. 44, where after arguing that only a "modified enthusaim" came to Africa under the heading of "the New Prophecy" and not a schismatic heresey known as "Montanism", Rankin asserts, "Given that the African religious style tended towards the severe, it is probable that Montanism found a congenial 'home' among sections of the population there"; Tabbernee, Montanist Inscriptions, 57-9, 117, concludes that it is "possible" only in a "pro-Montanist" sense, not in a schismatic one; in other words the martyrs "were not actually Montanists"; however, Trevett, Montanism, 70, claims the passio to be "Montanist-edited." Most recently, Rex D. Butler, The New Prophecy \& "New Visions": Evidence of Montanism in The Passion of Perpetua and Felicitas, (Washington, D.C.: Catholic University of America Press, 2006), argues for a return to the traditional reading of the passio as an entirely Montanist work. See the review of Butler, Wilhite, Journal of Religious History (forthcoming).

66 Janssen, "'Superstitio' and Persecution," 82.

67 Barnes, "Pagan Perceptions," 233; and Musurillo, The Acts, 1xi-ii.

68 "Why were the Christians Persecuted?" in Church and State in the Early Church, ed. Ferguson, 24. Also, Grig, Making Martyrs, 12.

69 cf. Henrichs, "Pagan Ritual," 21, who stresses the role of the elites over the plebs. For North Africa, see Trevette, Montanism, 69-70.

70 Wilken, The Christians, 15; ref. Pliny, Epistula 10.96.10. 
It appears that Trajan's directive, conquirendi non sunt, was generally observed by provincial leaders, yet when the status quo of a certain demographic in the local population was challenged, as in the case of idols and sacrificial meat not selling, the Roman officials took action against the group causing the disturbance. $^{71}$

In Africa where new elites mediated religion between the Roman colonizers and the indigenous Africans in order to establish themselves in a special status in the eyes of both groups, any disturbance of the practice of the Afro-Roman sacrifices and rituals would have greatly threatened their position. Can we assume that Christians were not "sought out" by the Roman colonizers themselves, but by the new elites defending their special status? Could this explain the more violent tone of the attacks of the new elite such as Fronto and Apuleius on Christianity? ${ }^{72}$

In searching for indications of the cause of Christian persecution in North Africa, Musurillo warns scholars, "It is clear that such texts [the acta] can be used to support all theories or none at all." "73 Wypustek finds evidence of superstitio in the account of the Scillitan's trial: "If you return to your senses, you can obtain the pardon of our lord the emperor."74 No mention, however, is made in the account of the Scillitan's trial of who brought the charges against the Christians. One clue may lie in the enigmatic exchange between the official and the Christian spokesperson:

\section{[Proconsul] Cease to be of this persuasion.}

[Speratus] It is an evil persuasion to commit murder, to bear false witness. $^{75}$

How does Speratus' response answer the proconsul? Perhaps he declares that to deny being a Christian would "bear false witness." Yet, this does not explain what committing "murder" has to do with the line of questioning. The Scillitan Christian could have been indicating something about those who brought charges against him and the other Christians; that is, they are of the "evil persuasion to murder, to bear false witness" by alleging that the Christians were to blame for the decline in the worship of Roman-translated African gods.

71 Musurillo, The Acts, Ixi-lxii; who adds, “...this would be particularly hard on the humiliores and the non-citizen classes (to which most Christians belonged before the Constitutio Antoniana of A.D. 212.)" cf. Acts 19:23-41.

72 See above, section 2.3.3.

73 Musurillo, The Acts, lviii.

74 Wypustek, "Magic," 277; ref. PSS 2: Potestis indulgentiam domni nostri imperatoris promereri, si ad bonam mentem redeatis.

75 PSS 7: Saturninus proconsul dixit ceteris: Desinite huius esse persuasionis. Speratus dixit: Mala est persuasio homicidium facere, falsum testimonium dicere. 
Although the Passio sanctarum Perpetuae et Felicitatis tells that the new Christians apprehensi sunt (2.1), it does not report why or by whom. If one can assume that Trajan's instructions not to seek out the Christians were heeded by Roman provincial leaders, then one must conclude that someone brought the accusation before the Roman officials. The narrator reports that Perpetua and her companions were treated harshly "because from the intimations of certain deceitful men, [the tribune] feared lest they should be withdrawn from the prison by some sort of magic incantations." 76 The label "deceitful men" echoes the denunciation of Speratus of those who "bear false witness," and strengthens the conclusion that the narrator is referring to those who "betrayed" (tradiderat, 4.5) the North African Christians to the Roman officials. ${ }^{77}$ Given that Perpetua's confrontation with the official in the next line calls into question the emperor himself, one wonders what part the most well-known and successful African new elite, Septimius Severus, played in the persecution of Christians. ${ }^{78}$

Many scholars recognize the numerous indicators of Septimius' views towards Christianity. Some have highlighted the outbreak of persecutions that followed the emperor's visit to Egypt and declared that Septimius produced an edict launching an empire-wide persecution. ${ }^{79}$ The Scriptores Historiae Augustae refers to Severus' prohibition of Jewish and Christian proselytizing, and the issue has "become a matter of continuing dispute among scholars." that the passage is of a "fictional nature" and the correlation of the emperor's visit

76 PSPF 16.2-4: quia ex admonitionibus hominum uanissimorum uerebatur ne subtraherentur de carcere incantationibus aliquibus magicis. The English translation is that of R.E. Wallis, "The Passion of the Holy Martyrs Perpetua and Felicitas" in ANF 3, as opposed to Musurillo who translates hominum uanissimorum as "very foolish people" which neglects the self-serving and dishonest insinuations of the phrase in this context.

77 For the pattem of local elites sponsoring local festivals and games in order to establish their own political identity, see Onno Van Nijf, "Athletics, Festivals and Greek Identity in the Roman East," PCPS 45 (1999): 176-200.

78 PSPF 16.2-3: "Perpetua spoke to him directly. "Why can you not even allow us to refresh ourselves properly? For we are the most distinguished of the condemned prisoners, seeing that we belong to the emperor; we are to fight on his very birthday. Would it not be to your credit if we were brought forth on the day in a healthier condition?" [In faciem ei Perpetua respondit: 3 Quid utique non permittis nobis refrigerare noxiis nobilissimis, Caesaris scilicet, et natali eiusdem pugnaturis? aut non tua gloria est, si pinguiores illo producamur?] See discussion in W.H.C. Frend, "Open Questions Concerning the Christians and the Roman Empire in the Age of the Severi," JTS n.s. 25 (2 1974): 333-51.

79 Birley, The African Emperor, 135, rejects such a conclusion.

80 Wypustek, "Magic," 285; Scriptores historiae augustae, Seuerus, 17.1: "He forbade conversion to Judaism under heavy penalties and enacted a similar law in regard to the Christians." [Iudaeos fieri sub graui poena uetuit. Idem etiam de Christianis sanxit.] Frend, "Open Questions," 340, argues there was such an edict; Robeck, Prophecy, 11, concurs. cf. Tert., Ad Scap. 4.5-6. 
and the outbreak of persecution is mere coincidence. ${ }^{81}$ The coincidence is repeated, however, when the imperial family celebrates the birthday of Geta Severus, Septimius' son, in Carthage on the same day as the torture and execution of Perpetua and her fellow-martyrs. ${ }^{82}$

Moreover, beyond the chronological coincidence, historians have seen other factors that point towards the emperor's involvement in the persecution of Christians. Pointing to the Severan lawyer, Julius Paulus, who left an outline of legislation against the magicians, astrologers, and prophets, Wypustek argues that the law would have included Christians. ${ }^{83}$ Another factor in interpreting the persecutions in North Africa that took place under Septimius' reign is the emperor's relationship to the new elite of Africa. Although in 197 Septimius executed twenty-nine senators with connections to North Africa upon the defeat of Albinus - a rival who was also from Africa, the emperor "also entrusted a high proportion of key provinces, with large armies attached, to men of African origin or connection." 84 Moreover, Raven notes that the indigenous African gods were prevalent during this time, even among the administration of the Roman armies. ${ }^{85}$ The new elites, placed into such close proximity in status with the Roman/African Emperor, could not afford to allow the religion which played such a key role in establishing themselves as mediators between Romans and indigenous Africans to decline because of a new secretive and seemingly subversive religion.

Whether or not historians will ever be able to agree on the cause or legal basis of Christian persecution in North Africa, the sources do suggest that new elites of Africa were threatened by the new religion. In the second period of African history, African Christians will continue to suffer at the hands of Roman officials, but this time the persecution will extend to Christians throughout the Roman Empire under Decius, and within the Christian religion, conflict would persist between the diocese of Rome and of Carthage. ${ }^{86}$

$\overline{81}$ Septimius, 210 ; cf. his deduction from the chronological coincidence in another instance (221): "...While the Emperor and his party were in Africa, the proconsul died. It may have been from natural causes. But the fact that Plautinus was there at the time makes one wonder."

82 PSPF 16.2-3; Birley, Septimius, 221, believes, "The imperial party would have been otherwise occupied."

83 Wypustek, "Magic," 276; ref. Paulus, Sententiae 5.21.1-3, 5.23.

84 Rankin, "Tertullian and the Imperial Cult," SP 34 (2001), 209; Rankin also discusses how "The author of the Historia Augusta even ventures that this 'murderer (interfector)' of so many of high estate "was regarded by the Africans as a god"; ref. Scriptores historiae augustae, Seuerus. 13.8-9: ab Afris ut deus habetur.

85 Rome, 145.

86 On Cyprian, see M. Bevenot, The Tradition of Manuscripts : a Study in the Transmission of St. Cyprian's Treatises, (Oxford: Clarendon Press, 1961); Burns, "On Rebaptism," 377; von Campenhausen, The Fathers, 55; and Rankin, Tertullian, 14-15. On the Donatists, see Raven, Rome, 177; Shaw, "African Christianity," 13; and Tilley, The Bible, 1-2. 